\title{
The Challenges and the Needs of Partnership in the Implementation of Healthy Cities in Indonesia: A Case Study of Makassar
}

\author{
Sukri Palutturi \\ Hasanuddin University, Makassar, Indonesia \\ Shannon Rutherford, Peter Davey, Cordia Chu \\ Griffith University, Brisbane, Australia
}

\begin{abstract}
Partnership in the implementation of the "Healthy Cities" was a key determinant. This study aimed to identify the challenges of the partnership and assess the needs of stakeholders to strengthen the partnership among the central government, provincial, and municipality toward the implementation of the "Healthy City" in Makassar, Indonesia. This study was a qualitative research with a case study approach. Data analysis used a thematic analysis. Informants were policy makers at central, the provincial, and city levels. At city level, this research involved Healthy City Advisory Team (HCAT) and Healthy City Forum (HCF). This study identified the challenges faced in the implementation of the "Healthy City" occurred at the central level and the city level. Future needs for the budgeting of the "Healthy City" were the budget that was distributed on every setting but still under the control of advisory team. This study also recommends the need for a presidential decree on the implementation of the Healthy Districts/Cities in Indonesia that has a strong tie to the relevant ministries. This study can be used as consideration for local government, especially for the forum and the advisory team to achieve a better healthy city: clean, safe, comfortable, and healthy.
\end{abstract}

Keywords: partnership, government, Healthy Cities, Makassar, Indonesia

Healthy City concept was formally introduced by Kickbusch in 1986 when the WHO (World Health Organization) held a conference in Copenhagen, Denmark. This concept aims to develop an effective strategy in an effort to overcome the problems of urban health (Ashton, 2002; Hancock, 1993). The Healthy Cities approach was a setting approach, providing more space and more complex than other setting elements,

Corresponding author: Sukri Palutturi, Ph.D., senior lecturer, School of Public Health, Hasanuddin University, Indonesia; research fields: health policy and administration, healthy settings and healthy cities, partnership and urban planning. E-mail: sukritanatoa72@gmail.com.

Shannon Rutherford, Ph.D., senior lecturer, Centre for Environment and Population Health, Griffith University, Australia; research fields: occupational and environmental health, public health leadership, and capacity building. E-mail: s.rutherford@griffith.edu.au.

Peter Davey, Ph.D., senior lecturer, Centre for Environment and Population Health, Griffith University, Australia; research fields: healthy cities, climate change, and disaster management. E-mail: peter_davey2002@hotmail.com.

Cordia Chu, professor, Centre for Environment and Population Health, Griffith University, Australia; research fields: international development and global health, health promotion and population health, climate change and health, healthy settings (including cities, schools, workplaces, and hospitals). E-mail: c.chu@griffith.edu.au. 
including Healthy Schools, Healthy Workplaces, Healthy Villages, Healthy Markets, or Healthy Hospitals. In health promotion efforts, this approach was seen as the most effective means for this approach to prepare a mechanism for each member and the policy makers and establish rules for members and institutions involved in these settings. Healthy Cities, in addition, also integrated the environmental aspects and population health issues in health planning. The WHO further explained that the settings approach was the main feature that distinguished between Healthy Cities with other health programmes (World Health Organization [WHO], 2002).

In the implementation of Healthy Cities, the WHO stressed that partnership with various sectors was a major determinant. However, the implementation of the "Partnership" was not easy to do. Experiences in various countries had shown a variety of challenges in the Healthy Cities programme. Partnerships involved many people and sectors (Barton \& Tsourou, 2002). They had different cultural backgrounds and experiences, even had different needs. A partnership requires a shared commitment where all partners have a right and an obligation (Primrose, Paul, \& Chrispen, 2013). Partnership is needed for many areas such as transport, public services, environment, and health care (Abidinovna, 2014). These factors affected the partnership in the implementation of the Healthy Cities. The challenges of partnership could be structural challenges, procedural challenges, financial and programmatic challenges, professional challenge, challenge of the status and legitimacy, and recognition challenges (Palutturi, 2014).

Issues concerning the importance of the partnership had been expressed in various international forums and the issue even became a central theme, for example, Jakarta Declaration (1997) and Bangkok Conference (2005). Jakarta Declaration (1997): New Player for New Era-leading health promotion into the 21st century (WHO, 2011). The theme of the conference held in Bangkok was "Policy and Partnership for Action: Addressing the Determinants of Health" (Barry, Allegrante, Lamarre, Auld, \& Taub, 2009; Porter, 2007; Smith, Tang, \& Nutbeam, 2006; WHO, 2001). This conference recognized the importance of partnerships in tackling the increasingly complex health problems and even the conference conducted in Indonesia was the first conference involving the private sector optimally.

There were a lot of researches and publications identified the challenges and success factors in the implementation of the Healthy Cities, such as a research conducted by Bauld and Langley (2010), Holtom (2001), Hudson and Hardy (2002), and Israel, Schulz, Parker, and Becker (1998). The existence of a number of these studies provided benefits in this study as a background. Previous studies also recognized that the implementation of the Healthy Cities was at the municipality level (Palutturi, Rutherford, Davey, \& Chu, 2013b).

Cross-sectoral cooperation by government agencies, private sector, and civil society organizations was crucial for effective implementation of the Healthy Cities (WHO, 2002). Partnership was also important for the context of Indonesia (Palutturi, Rutherford, Davey, \& Chu, 2013a). Strong synergy was highly needed between central government through the Ministry of the Home Affairs and the Ministry of Health, with the provincial government and districts/cities as stipulated in joint regulation of the Implementation of Healthy Districts/Cities in Indonesia in 2005 (Palutturi et al., 2013a; Palutturi et al., 2013b).

\section{Research Method}

This research used a qualitative research with a case study design. The case study approach was able to practically explore and to identify an existing phenomenon to actual life problems (Baum, 2008).

This research focused at Makassar City as a capital city of South Sulawesi, Indonesia. Makassar was selected as a place for the research, because Makassar had experienced to be a successful city in the 
implementation of Healthy Cities in Indonesia. Makassar had achieved all levels of award for Healthy Cities, in Indonesia, namely: Swasti Saba Padapa (basic achievement), Swasti Saba Wiwerda (middle achievement), and Swasti Saba Wistara (highest achievement).

Informants at the central government level were five participants, they were the staff of Ministry of Home Affairs and the Ministry of Health, were responsible for Healthy Cities. Informants at provincial level were five people: Health Office Staff in the Department of Disease Control and Environmental Health. And at city level, there were 10 people, the informants at city level were from the Advisory Healthy City Team and the Healthy City Forum. The Advisory Team members were from government representative (Regional Planning and Development Board, District Health Office, Social Affairs Office, Hygiene and Park Department, and Tourism), while the members of Healthy City Forum generally came from the community or university representative. In-depth interview and document review were conducted in this research.

This research used a thematic analysis. Such approach was often conducted in a qualitative research (Bryman, 2012; Liamputtong, 2012; Neuman, 2011). Five stages to apply the thematic analysis of this research were reading, coding, displaying, reducing, and interpreting (Ulin, Robinson, \& Tolley, 2005).

\section{Reading}

This step was the first stage in the qualitative research. At this process, the researchers re-read and reviewed the note/transcript carefully. This step aimed to convince that data collection was valid. The researchers also had conducted an interpretation process at this stage, once data collection was conducted.

\section{Coding}

The second stage was coding process. At this stage, the researchers needed to choose what words should be used as a label. This was an important point that could be used to label the informant's response. When all the topics had been given a code, the second stage of coding was re-reading all of the coding matrixes to find the differences and similarities between groups.

\section{Displaying}

Once all the data had been encoded, the researchers had to display all the available information. In this stage, the analysis of qualitative data had to be able to demonstrate that the data had been labeled and made themes. This stage aimed to find relationships between themes.

\section{Reducing}

The purpose of this process was to define and distinguish the main theme (primary theme) and the second theme and decided the most common themes. This stage was important because the researchers collected data that might not be needed or the data collected was not associated with this research.

\section{Interpreting}

The process of interpretation was the ongoing process at each stage of data analysis. In this process, the analyst needed to explain the main information prepared on the data collected. The researchers had to ensure that the interpretation was reliable.

\section{Result and Discussion}

This study was conducted at the central, provincial, and municipal levels. This study was expected to obtain comprehensive information on their contribution to healthy city at each level. At the central government, 
the partnership was assessed horizontally and vertically, in terms of cooperation among the Ministry of Home Affairs, the Ministry of Health, and other Ministries that involved in the implementation of the Healthy City in Makassar.

It was also assessed the role of the central government to the province and city in the implementation of the Healthy City in Makassar. The study also examined the contribution of the central government to the provincial government and central government to the city of Makassar. Another aspect, the study also examined the contribution of the provincial government to the City of Makassar in the implementation of the Healthy City. Thus, this study would be more comprehensive. Data collection was conducted from September to October, 2014.

\section{The Challenge of Partnership During the Implementation of Healthy City}

In the implementation of the Healthy City or Healthy District, there were many challenges faced by Indonesia Government. These challenges could occur at almost all level of government, at both the central and local government. However, there were also several success factors as determinant of success of in the implementation of the Healthy City or Healthy District. These challenges and the success factors were identified for further analysis.

\section{The Challenge in the Central Government}

The central government had a vital role in the implementation of the Healthy City or Healthy District in Indonesia. If central government was successful, then it would certainly affect the provincial and district government; on the contrary, if it failed, then it would also give negative impact. According to the staff of the programme of the Healthy City in Indonesia, there were two main obstacles faced by central government to implement a strong partnership in the implementation of Healthy City, i.e.: Sectoral ego was so strong, each ministry only concerns on their direct duties and responsibilities. The wrong perception of the word Healthy City, because they think that was the main duty of the Ministry of Health or only to the Health Sector. Of course, this perception was totally wrong, because out of nine settings of healthy city, only one setting was directly related to the Health Department, i.e., the programme of Healthy and Independent Community.

The position of the Ministry of Home Affairs was not strong enough in the presence of the joint regulation, because of the cooperation only between the Ministry of Health and the Ministry of the Home Affairs. The expectation to involve the Ministry of Home Affairs, i.e., it might affect other ministries to implement Healthy City. However, in reality, each ministry only concerns on their main duties and responsibilities. There was no dependence among the ministries related to the implementation of healthy city/healthy district. The impact of such situation would affect the local government.

\section{The Challenge in Provincial Government and Municipality Government}

The problems faced by the provincial government and the municipality were similar to the problems faced by the central government, i.e., the aspect of egoism and the wrong perception on the word Healthy City. There was no problem on the role of Regional Planning and Development Board, because it could promote other sectors to implement the programme according to their job. Moreover, their primary duty at the provincial level was to be a coordinator office.

While in the municipality office, there were some obstacles in the implementation of the Healthy City in Makassar, as follows: 
First, there was the problem of funding. At the beginning of the implementation of Healthy City in Makassar, there was no allocation of budget from the central government and the municipality office. The matter was the municipality did not know what kind of fund should be allocated by the city government. Because of the awareness of the city government led by the Mayor of Makassar Ilham Arief Sirajuddin and Deputy Mayor of Makassar Supomo Guntur, then the municipality started to provide budget for Healthy City programme. However, the funding was allocated directly through the head of government offices and bodies and not to the Healthy City Forum.

The consequences came to the Healthy City Forum that faced some difficulties to implement some activities because the funding was at SKPD (local offices administered by municipality). Healthy City activities should be through SKPD. Therefore, the activity of Healthy City Forum should be relevant to the activity of SKPD, because the budget was given by SKPD. The budget for Healthy City Forum was not maximal because of the position of Healthy City in Makassar and not Healthy City of District Health Office.

It was based on the selected settings. Therefore, ideally, the budget for Healthy City Forum could be taken from several offices based on setting, for example, the setting associated with the improvement of healthy social life, then the budget could be derived from District Health Office. Another example was the setting of housing, general structure and infrastructure, then the budget could be derived from the office of Public Works or the office of Parks and Hygiene Department.

Still related to the budget allocation, the programmes funded some activities, i.e., socialization, the meeting of member of Healthy City Forum and incentives for member of the forum. There was no synchronization of budgeting for Healthy City Policy. Healthy City Forum did not know how much the budget allocation for a particular field, including its utilization. More comprehensive planning mechanisms needed to be strengthened between the supervisory board and the Healthy City Forum.

Second, there was the problem of the secretariat. The secretariat was not adequate for both the supervisory board and Healthy City Forum. There was a secretariat of the Forum, but the room was very small. The room could put only two or three tables. The room did not support the activity of the forum.

Therefore, when there was a meeting of the forum, the member of the meeting should find another room such as the room in the city hall or even the room in District Health Office. However, not only the Healthy City Forum used the room, but also so did the other programmes, this could become an obstacle for the work of the forum.

In addition, the room was so small and narrow, while the infrastructure did not support to run the programme of the Healthy City. The unavailability of the internet network, computer available was not sufficient to publish some activities of the forum, including the success story of the forum. Another obstacle was the absence of a special person who handled the Healthy City in each SKPD (local offices administered by municipality), sometimes it could also be an obstacle to make a coordination.

\section{The Need of Stakeholder to Strengthen the Partnership of Healthy City}

Almost at all levels of the government, especially in non-health ministries, they had the notion that a healthy city was a business of the health sector.

This indicated that although there was a joint regulation between the Ministry of Home Affairs and the Ministry of Health, but it did not run optimally.

It was because the position of the Ministry of Health, Provincial Health Office and District Health Office 
got a duty to provide technical guidance as well as to be secretary of the supervisory board. Therefore, many activities required direct involvement of the District Health Office. So, there was a need to conduct socialization for the future plan.

The socialization could take the role to disseminate information related to a healthy city. Socialization was carried out to all offices of SKPD and to the community.

Public Relation Office of Makassar City Hall should explain to the public through the media about the Healthy City. The media could be either electronic media, i.e., TV, radio, or printed media.

Another problem encountered was a lack of supervisor in assisting the community. As a result, the frequency of activities was quite limited in conducting direct contact with the community. Many activities of Healthy City reached only to the level of District or Healthy Village Communication Forum. As a result, the involvement of Working Group was less active, though the main actor was at the level of POKJA at the subdistrict. The more activities at the community level, then the more the need to involve the community. Thus, they would have comprehensive knowledge on Healthy City.

Another problem was the lack of budget, the budget for implementing the programme or the budget for implementing Healthy City Programme. For example, Healthy City Forum needed some money to publish a website so that by this means, Healthy Cities Programme in Makassar could be widely distributed to all level of community. Therefore, there should be allocation of budget to publish a website of healthy city. The Healthy City Forum needs to provide advocacy to the government and local representatives for additional budget for healthy city.

There is a need to have administrative staff who is intensively work on the forum, because many activities are abandoned in the absence of this staff. The administrative staff will help the forum to prepare operational activities in the implementation of Healthy City in Makassar. For example, there are some activities from the central government or provincial government to make socialization of the Presidential Decree draft on the implementation of the Healthy City/Healthy District in Indonesia. Then, the administrative staff could socialize the decree to the related offices. Administrative staff could be from the government or from the community facilitated by the government.

The summary of various problems and challenges faced during the implementation of the Healthy City in Makassar, and the need from all level are shown in Table 1.

Table 1

The Challenges and the Needs at Each Policy Level for the Healthy City Implementation in Makassar, Indonesia

\begin{tabular}{|l|l|l|}
\hline Policy level & The challenges & The needs \\
\hline Central & $\begin{array}{l}\text { Sectoral ego } \\
\text { Misunderstanding on Healthy City }\end{array}$ & $\begin{array}{l}\text { Advocacy to make a new presidential decree on Healthy City } \\
\text { Advocacy to other ministries }\end{array}$ \\
\hline Provincial & $\begin{array}{l}\text { Lack of support from beyond health sectors } \\
\text { No integrated planning for Healthy } \\
\text { Cities/Districts development }\end{array}$ & $\begin{array}{l}\text { Strong coordination amongst districts/cities } \\
\text { Budgeting support for successful districts/cities } \\
\text { Advocacy to other departments/offices } \\
\text { Strengthening Provincial Healthy Cities Forum }\end{array}$ \\
\hline City & $\begin{array}{l}\text { Sectoral ego } \\
\text { Limited budget } \\
\text { Misunderstanding on Healthy City }\end{array}$ & $\begin{array}{l}\text { Subdistrict Forum and Working Group City programme to } \\
\text { Providing Healthy City's handbook and guidance } \\
\text { Budgeting on each sector based on selected programme but } \\
\text { under the control of supervisory board } \\
\text { Administration } \\
\text { Staff recruitment for the forum }\end{array}$ \\
\hline
\end{tabular}

Note. Source: primary data (interview and document review). 


\section{Conclusions}

Challenges faced in the implementation of Healthy Cities in Makassar, Indonesia, occurred at the central government. They included sectoral ego, misunderstanding concept of Healthy Cities. Another challenge was on the inability of the Ministry of Home Affairs to coordinate to other ministries at the central level to encourage the implementation of the Healthy City in accordance with the selected settings. The challenges at city level were generally in the form of limited budget, the secretariat, and other facilities that could support the Healthy City. The most dominant success factor of the Healthy City award that had been achieved today was more influenced by the strong political will of the municipality government.

To implement an effective Healthy Cities, improving understanding of Healthy Cities for the relevant stakeholders needed to be strengthened. Recruitment of administrative personnel for Healthy Cities Forum was necessary. This research also recommended that encourage the new policy in the implementation of Healthy Cities in Indonesia, i.e., a Presidential Decree that had a strong tie and leverage to other ministries and other sectors.

\section{References}

Abidinovna, T. Z. (2014). Trends of public-private partnership improvement in regional tourism industry. World Applied Sciences Journal 30 (Management, Economics, Technology \& Tourism) IDOSI Publications, 206-207. Retrieved from http://www.cabi.org

Ashton, J. R. (2002). Healthy cities and healthy settings. Promotion \& Education, 9(1), 12.

Barry, M. M., Allegrante, J. P., Lamarre, M. C., Auld, M. E., \& Taub, A. (2009). The Galway Consensus Conference: International collaboration on the development of core competencies for health promotion and health education. Global Health Promotion, 16(2), 5-11.

Barton, H., \& Tsourou, C. (2002). Healthy urban planning: A WHO guide to planning for people. London: Spon Press for the World Health Organization Regional Office.

Bauld, L., \& Langley, D. (2010). Learning from the partnership literature: Implications for UK University/national health service relationships and for research administrators supporting applied health research. Journal of Research Administration, 41(1), 49-64.

Baum, F. (2008). The new public health. South Melbourne, VIC: Oxford University Press.

Bryman, A. (2012). Social research methods. Oxford: Oxford University Press.

Hancock, T. (1993). The evolution, impact and significance of the health cities/healthy communities movement. Journal of Public Health Policy, 14(1), 5-18.

Holtom, M. (2001). The partnership imperative: Joint working between social services and health. Journal of Management in Medicine, 15(6), 430-445.

Hudson, B., \& Hardy, B. (2002). What is a successful partnership and how can it be measured. In C. Glendinning (Ed.), Partnerships, new labour and the governance of welfare (pp. 51-65). Bristol, UK: Policy Press.

Israel, B. A., Schulz, A. J., Parker, E. A., \& Becker, A. B. (1998). Review of community-based research: Assessing partnership approaches to improve public health. Annual Review of Public Health, 19(1), 173-202.

Liamputtong, P. (2012). Qualitative research methods. Melbourne, VIC: Oxford University Press.

Neuman, W. L. (2011). Social research methods: Qualitative and quantitative approaches. Boston, MA: Pearson.

Palutturi, S. (2014). Public health leadership. Yogyakarta: Pustaka Pelajar.

Palutturi, S., Rutherford, S., Davey, P., \& Chu, C. (2013a). Comparison between healthy cities and Adipura in Indonesia. Malaysian Journal of Medicine and Health Sciences, 9(1), 35-43.

Palutturi, S., Rutherford, S., Davey, P., \& Chu, C. (2013b). Healthy cities implementation in Indonesia: Challenges and determinants of successful partnership development at local government level. Griffith University, Brisbane, Australia.

Porter, C. (2007). Ottawa to Bangkok: Changing health promotion discourse. Health Promotion International, $22(1), 72$.

Primrose, K., Paul, M., \& Chrispen, C. (2013). Unmasking the role of collaboration and partnerships in open and distance learning systems. World Journal of Management and Behavioral Studies IDOSI Publications, 1(2), 36-43. 


\section{A CASE STUDY OF MAKASSAR}

Smith, B. J., Tang, K. C., \& Nutbeam, D. (2006). WHO health promotion glossary: New terms. Health Promotion International, 21(4), 340 .

Ulin, P. R., Robinson, E. T., \& Tolley, E. E. (2005). Qualitative methods in public health: A field guide for applied research. San Fransisco: Jossey-Bass.

WHO (World Health Organization). (2001). Jakarta Declaration on leading health promotion into the 21st century. Retrieved from http://www.who.int/healthpromotion/conferences/previous/jakarta

WHO (World Health Organization). (2002). Healthy cities initiative: Approaches and experiences in the African region. Brazzaville: World Health Organization. 